\title{
Organic summer squash production using chicken manure, compost and AMF for enhancing soil fertility
}

\author{
${ }^{1}$ Amal K. Abou El-Goud and ${ }^{2}$ Mona M. Yousry
}

\author{
${ }^{1}$ Department of Botany, Organic Agriculture, Faculty of Agriculture, Damietta University, Egypt \\ ${ }^{2}$ Department of Plant Production, Vegetable, Faculty of Agriculture, Saba Basha, Alexandria \\ University, Egypt
}

Received: 10 Oct. 2019/ Accepted 20 Nov. 2019/ Publication date: 25 Nov. 2019

\begin{abstract}
Two field experiments were conducted at the Faculty of Agriculture, (Saba-Basha) - Alexandria University, during the growing seasons of 2017 and 2018, in order to study the effect of organic and bio fertilizer such as chicken manure, Compost and AM fungi on yield and quality of summer squash (El-Askandarani sp.). The study was conducted with randomized complete block design with three replicates. Eight treatments were carried out in this investigation i.e. (AM fungi , $100 \%$ compost, $100 \%$ chicken manure, $50 \%$ compost $+50 \%$ chicken manure, $50 \%$ compost + AM fungi, $50 \%$ chicken manure $+\mathrm{AM}$ fungi, 33.5\% compost $+33.5 \%$ chicken manure $+\mathrm{AM}$ fungi and the recommended doses of chemical fertilizers N,P,K as a control ). The effects of the treatments on the growth, yield and plant nutrient elements of leaves and fruits of summer squash were determined. The results indicated that using 50\% chicken manure + AM fungi improved significantly vegetative growth characters ( plant height, No. leaves/plant, leaf area index, shoot and root dry weight and nutritional status of plants in leaves and fruits) except $50 \%$ compost $+50 \%$ chicken manure gave the highest values in chlorophyll reading of leaves. Treatments of chicken manure increased significantly all morphological characteristics and qualities of squash. Also, AM fungi additions led to increase mineral content of leaves and fruits compared with control treatment. In our experience, add two types of organic fertilizers to cultivated squash with addition of AM fungi had different effects on the quality and quantity of the yield. The highest values of early and total yield production was achieved by the combination of $33.5 \%$ compost $+33.5 \%$ chicken manure + AM fungi compared to the control treatment. Also, the use of $100 \%$ chicken manure was increased values of the fruit length, fruit diameter and average fruit weight significantly compared to data recorded by the control. This study demonstrated the possibility of producing a good yield of squash safe and healthy without any applying chemical fertilizers via integration of compost, chicken manure and AM fungi as cleanly fertilizers and environmentally friendly practices.
\end{abstract}

Keywords: Chicken manure; compost; AM fungi and summer squash organic production.

\section{Introduction}

Summer squash (Cucurbita pepo L.), is one of the most important crop of the family Cucurbitaceae, and highly polymorphic vegetable grown during summer in tropical and subtropical conditions. The total cultivated area in Egypt was 59340 feddans (feddan $=0.42$ hectare), produced about 455866 tons on annual basis with an average of 7.682 tons/feddan (Ministry of Agriculture and Land Reclamation, 2015). Squash is very rich in nutrients and bioactive compounds such as flavonoids, vitamins, amino acids, carbohydrates and minerals (especially potassium), and it is also low in calories and high percentage of fiber. It has various medicinal effects such as comprising antidiabetic, antitumor, antimutagenic, antibacterial, and anti-inflammation affects.

Organic plant production aim to produce healthy food without causing adverse effects on the natural environment. This goal can be achieved through the use of non-chemical nutrients such as the mixture of organic and biofertilizers (Abou-El-Hassan et al., 2017).

The organic manures such as chicken manure play an important role in increasing growth, yield and yield components of many crops. Abd El-Rahman and Hosny (2001) stated that using organic

Corresponding Author: Mona M. Yousry, Department of Plant Production, Vegetable, Faculty of Agriculture, Saba Basha, Alexandria University, Egypt.

E-mail: mona.yousry25@yahoo.com 
manure improved the yield and yield components of egg-plant fruits. Organic manures increase the organic matter in the soil. Organic matter in turn releases the plant food in the available form for the use of crops. However, organic manures should not be seen only as carriers of plant food. These manures also enable a soil to hold more water and also help to improve the drainage in clay soils Singh et al., (2012).

Application of compost to soil improves their physical, chemical and biological characteristics, such as retention water, aggregation, porosity, increasing of cation exchange capacity and fertility. Also, increasing of microbial and biological activities in the rhizosphere (Abou-El-Hassan et al., 2014).

Several studies confirmed the contribution of mycorrhizae to P uptake efficiency. AM fungi inoculation might become very important for sustainable agronomical management, especially in cases when the efficiency of native inocula is poor soil (Pellegrino et al., 2011) leading to an increase of the P absorbing surface area, the production of organic acids and phosphatase which catalyze the release of $\mathrm{P}$ from organic complexes (Wang et al., 2004 ). Enhancement of P uptake by mycorrhizal hyphae can also be indirectly attributed to the faster uptake rate of $\mathrm{P}$ by the hyphae and the disturbance of the solution solid $\mathrm{P}$ equilibrium, which will increase the sorption of absorbed phosphate into soil solution (Abou El seoud, 2005; Soil Health, 2010; Rouphael and Cardarelli, 2010, Tawaraya et al., 2012 and Al-Hmoud and Al-Momany, 2017).

The purpose of this study to obtain the excellent potential organic farming management by addition of chicken manure, plant composted, AM fungi only or mixed with each other on vegetable growth, yield and quality of squash (Cucurbita pepo L.) [El-Askandarani sp.] compared to chemical $\mathrm{N}, \mathrm{P}, \mathrm{K}$ fertilizers(control treatment). The beneficial effect of organic fertilizers and mycorrhizal fungi on the soil fertility to enhance and increase the availability of $\mathrm{N}, \mathrm{P}$ and $\mathrm{K}$, in order to decrease chemical pollutions and environmental protection.

\section{Materials and Methods}

Two field experiments were conducted at the Faculty of Agriculture (Saba-Basha), Alexandria University; during the summer growing seasons of 2017 and 2018. The experimental soil was sampled twice at the beginning of the growing season at the first season 2017 and in the end of second season (after 2018 season) as well as compost and chicken manure were analyzed for some physical and chemical properties according to the methods outlined in Page et al., (1982) as shown in Table (1, $2,3$ and 4$)$.

Table 1: Some physical and chemical properties of the experimental soil before growing season 2017.

\begin{tabular}{|c|c|c|c|}
\hline \multicolumn{4}{|c|}{ Soil properties } \\
\hline \multicolumn{2}{|c|}{ Particle distribution: } & \multicolumn{2}{|c|}{ Nutrients available $\left(\mathrm{mg} \mathrm{kg}^{-1}\right)$} \\
\hline Sand & $91.12 \%$ & KCl -extractable & 115.7 \\
\hline Silt & $4.0 \%$ & $\mathrm{NH}_{4}$-Ac- extractable (k) & 475 \\
\hline Clay & $4.88 \%$ & $\mathrm{NaHCO}_{3}$ - extractable (P) & 27.5 \\
\hline Texture class & Sand & Soluble cat & \\
\hline pH $\quad(1: 1)$ & 8.0 & $\mathbf{C a}^{2+}$ & 1.7 \\
\hline $\mathrm{EC}\left(\mathrm{dS} \mathrm{m}^{-1}\right) \quad(1: 1)$ & 0.37 & $\mathbf{M g}^{2+}$ & 2.04 \\
\hline Total $\mathrm{CaCO}_{3}$ & $28 \%$ & $\mathrm{Na}^{+}$ & 1.3 \\
\hline \multirow{5}{*}{ Organic matter } & $0.36 \%$ & $\mathbf{K}^{+}$ & 0.19 \\
\hline & & Soluble ani & \\
\hline & & $\mathrm{HCO}_{3-}$ & 5.45 \\
\hline & & Cl- & 1.48 \\
\hline & & $\mathrm{SO}^{2-}{ }_{4}$ & 0.19 \\
\hline
\end{tabular}


Table 2: Some physical and chemical properties of the experimental soil at the end of the second growing season 2018.

\begin{tabular}{|c|c|c|c|c|c|c|c|c|c|}
\hline \multirow{2}{*}{$\begin{array}{c}\text { Mechanical } \\
\text { Analysis }\end{array}$} & \multicolumn{9}{|c|}{ Soil properties of eight treatments after harvest (The end of season 2018) } \\
\hline & T1 & T2 & T3 & T4 & T5 & T6 & T7 & T8 & Unit \\
\hline Sand & 75.12 & 77.12 & 67.12 & 75.12 & 75.12 & 71.12 & 75.12 & 77.12 & $\%$ \\
\hline Silt & 12 & 12 & 12 & 12 & 12 & 16 & 12 & 12 & $\%$ \\
\hline Clay & 12.88 & 10.88 & 20.88 & 12.88 & 12.88 & 12.88 & 12.88 & 10.88 & $\%$ \\
\hline Textural & Sandy & Sandy & Sandy & Sandy & Sandy & Sandy & Sand & Sandy & Sandy loam \\
\hline class & loam & loam & loam & loam & loam & loam & loam & loam & \\
\hline pH (1:2) & 8.6 & 8.7 & 8.8 & 8.7 & 8.8 & 8.4 & 8.6 & 8.8 & \\
\hline EC (1:2) & 0.265 & 0.314 & 0.276 & 0.350 & 0.212 & 0.380 & 0.262 & 0.293 & $\mathrm{ds} / \mathrm{m}$ \\
\hline O.M & 0.52 & 0.36 & 0.72 & 0.36 & 0.72 & 0.52 & 0.92 & 0.48 & $\%$ \\
\hline O.C & 0.30 & 0.21 & 0.42 & 0.21 & 0.42 & 0.30 & 0.53 & 0.28 & $\%$ \\
\hline $\mathrm{C} / \mathrm{N}$ ratio & $30.46 / 1$ & $22.451 / 1$ & $41.76 / 1$ & $21.75 / 1$ & $28.00 / 1$ & $26.32 / 1$ & $41.69 / 1$ & $35.24 / 1$ & \\
\hline $\mathrm{CaCO}_{3}$ & 31.5 & 16.2 & 18.9 & 16.8 & 27.3 & 23.1 & 29.4 & 12.6 & $\%$ \\
\hline \multicolumn{10}{|c|}{ Soluble cations (meq / L ) } \\
\hline $\mathrm{Ca}^{2+}$ & 0.87 & 1.16 & 1.16 & 1.56 & 1.16 & 2.03 & 1.45 & 0.58 & $(\mathrm{meq} / \mathrm{L})$ \\
\hline $\mathrm{Mg}^{2+}$ & 0.29 & 1.16 & 0.29 & 0.58 & 0.29 & 0.87 & 0.29 & 0.58 & $(\mathrm{meq} / \mathrm{L})$ \\
\hline $\mathrm{Na}^{+}$ & 1.63 & 2.17 & 1.85 & 2.61 & 1.52 & 2.07 & 1.63 & 1.96 & $(\mathrm{meq} / \mathrm{L})$ \\
\hline $\mathbf{K}^{+}$ & 0.19 & 0.38 & 0.51 & 0.58 & 0.32 & 0.71 & 0.45 & 0.45 & $(\mathrm{meq} / \mathrm{L})$ \\
\hline \multicolumn{10}{|c|}{ Soluble anions (meq / L ) } \\
\hline $\mathrm{HCO}_{3}^{-}$ & 3.76 & 3.76 & 3.76 & 2.95 & 3.76 & 3.76 & 2.95 & 3.40 & $(\mathrm{meq} / \mathrm{L})$ \\
\hline $\mathrm{Cl}^{-}$ & 1.8 & 0.6 & 2.4 & 0.6 & 0.6 & 2.4 & 1.8 & 1.2 & $(\mathrm{meq} / \mathrm{L})$ \\
\hline $\mathrm{SO}_{4}^{2-}$ & 0.39 & 0.23 & 0.21 & 0.31 & 0.31 & 1.22 & 0.27 & 0.37 & $(\mathrm{meq} / \mathrm{L})$ \\
\hline \multicolumn{10}{|c|}{ Nutrients available $\left(\mathrm{mg} \mathrm{kg}^{-1}\right)$} \\
\hline$(\mathbf{N})$ & 99.44 & 92.54 & 100.00 & 96.00 & 150.21 & 113.81 & 128.18 & 79.13 & $(\mathrm{mg} / \mathrm{kg})$ \\
\hline (p) & 23.5 & 38.3 & 21.3 & 37.0 & 30.0 & 15.0 & 20.0 & 16.7 & $(\mathrm{mg} / \mathrm{kg})$ \\
\hline (k) & 650 & 650 & 675 & 650 & 575 & 600 & 600 & 650 & $(\mathrm{mg} / \mathrm{kg})$ \\
\hline
\end{tabular}

Table 3: Chemical analysis of compost during 2017-2018 seasons.

\begin{tabular}{|c|c|c|c|}
\hline \multicolumn{4}{|c|}{ Compost properties } \\
\hline pH (1:10) & 9.2 & KCl -extractable $\quad(\mathrm{N})$ & $3.0 \%$ \\
\hline$E C\left(d S ~ m^{-1}\right) \quad(1: 10)$ & 6.3 & $\mathrm{NH}_{4}$-Ac- extractable & $1.0 \%$ \\
\hline O.M & $15.2 \%$ & $\mathrm{NaHCO}_{3}$ - extractable (P) & $1.55 \%$ \\
\hline O.C & $8.8 \%$ & \multicolumn{2}{|c|}{ Soluble cations $(\mathrm{meq} / \mathrm{L})$} \\
\hline $\mathbf{C} / \mathbf{N}$ & 2.93 & $\mathrm{Ca}^{2+}$ & 1.48 \\
\hline \multirow[t]{6}{*}{ Moisture } & $30.6 \%$ & $\mathbf{M g}^{2+}$ & 2.45 \\
\hline & & $\mathbf{N a}^{+}$ & 38.04 \\
\hline & & $\mathbf{K}^{+}$ & 33.65 \\
\hline & & \multicolumn{2}{|c|}{ Soluble anions (meq / L ) } \\
\hline & & $\mathrm{HCO}_{3-}$ & 19.11 \\
\hline & & $\mathrm{SO}_{4}^{2-}$ & 17.63 \\
\hline
\end{tabular}

Table 4: Chemical analysis of chicken manure during 2017-2018 seasons

\begin{tabular}{|c|c|c|c|}
\hline \multicolumn{4}{|c|}{ Chicken manure properties } \\
\hline pH (1:10) & 7.2 & KCl -extractable & $4.7 \%$ \\
\hline $\operatorname{EC}\left(\mathrm{dS} \mathrm{m}^{-1}\right) \quad(1: 10)$ & 6.2 & $\mathrm{NH}_{4}$-Ac- extractable (k) & $1.0 \%$ \\
\hline O.M & $16 \%$ & $\mathrm{NaHCO}_{3}$ - extractable (P) & $1.64 \%$ \\
\hline O.C & $9.28 \%$ & \multicolumn{2}{|c|}{ Soluble cations $(\mathrm{meq} / \mathrm{L})$} \\
\hline $\mathbf{C} / \mathbf{N}$ & 1.97 & $\mathrm{Ca}^{2+}$ & 3.4 \\
\hline \multirow[t]{6}{*}{ Moisture } & $41.0 \%$ & $\mathbf{M g}^{2+}$ & 6.8 \\
\hline & & $\mathrm{Na}^{+}$ & 8.15 \\
\hline & & $\mathbf{K}^{+}$ & 17.95 \\
\hline & & \multicolumn{2}{|c|}{ Soluble anions (meq / L ) } \\
\hline & & $\mathrm{HCO}_{3-}$ & 40.0 \\
\hline & & $\mathrm{SO}^{2-}{ }_{4}$ & 22.93 \\
\hline
\end{tabular}

\section{Inoculum preparation of AM fungi:}

The mycorrhizal fungi were used in this experiment. The mycorrhizal specie was obtained from the Agricultural Research Center (ARC) Eldoky, Giza, Egypt. It was mixed with the seeds of squash three hours before sowing. At planting, three mixed seeds were dropped per hole and then irrigated with drip irrigation for a long time after sowing. 
Programmer of organic and bio fretilizers in summer squash (El-Askandarani sp.) were sowed during summer seasons 2017 and 2018 in open field at the experimental farm of Faculty of Agriculture, Saba Basha Alexandria University. Seeds were sown on $15^{\text {th }}$ and $17^{\text {th }}$ March in the first and second seasons, respectively. Eight treatments were carried out in this investigation i.e.:

1. AMF inoculum $(3 \mathrm{~g} / \mathrm{hill})$

2. $100 \%$ of plant composted ( 7 ton/ fed.)

3. $100 \%$ chicken manure $(3,5$ ton/ fed.)

4. $50 \%$ compost $+50 \%$ chicken manure

5. $50 \%$ compost + AMF inoculum

6. $50 \%$ chicken manure $+\mathrm{AMF}$ inoculum

7. $33.5 \%$ compost $+33.5 \%$ chicken manure $+\mathrm{AMF}$ inoculum

8. Control treatment (recommended doses of chemical fertilizer N, P and K).

Two experiments were carried out in a randomized complete blocks design with 3 replications (RCBD). Total plot area was $(3.5 \mathrm{~m}$ length $\times 0.8 \mathrm{~m}$ width) and the distance between two plants within row was $0.33 \mathrm{~m}$. Recommended amount of chemical N. P. K fertilizers were added only in control plots as followed: $250 \mathrm{~kg} / \mathrm{fed}$. of Ammonium Nitrate $(33.5 \%), 200 \mathrm{~kg} /$ fed. of Super calcium phosphate (15.5\%) and $150 \mathrm{~kg} /$ fed. of Potassium sulphate (48\%). Total amount of organic fertilizers were applied prior to planting and thoroughly mixed to the soil during plowing from 21 days before sowing.

Irrigation was added three times weekly and applied by drip-irrigation system. Weeds were controlled by hand-howling once a week after sowing, there were organic pesticides programme by using (Ashok) the neem oil extraction as a foliar applications on leaves at level: $3 \mathrm{~cm} / \mathrm{L}$ for every two weeks after 45 days from sowing and continued to the end of the harvest at $30^{\text {th }}$ June of two seasons to increase the defense of the plants against the insects in addition to cover the squash plants under net to protect them.

Six plants were randomly dug out from each experimental unit for determination of growth characteristics. Plant height $(\mathrm{cm})$, number of leaves/ plant, as well as shoot and root dry weights (g/plant), were recorded at the end of the growing seasons for leaves, roots and fruits. Total chlorophyll in green stage (SPAD), and leaf area index $\left(\mathrm{cm}^{2}\right)$ were measured according to Roods and Blood-Worth (1964). All parts of the vegetable samples of plants (leaves, roots and fruits) were washed by tap water then by distilled water and oven dried at $75^{\circ} \mathrm{C}$ for $48 \mathrm{~h}$ to determine dry weight.

Yield and its components: the early yield ( $\mathrm{kg} / \mathrm{fed}$.) was expressed as the sum of fruit weight of the first two pickings. Total yield $(\mathrm{kg} / \mathrm{fed}$.) was calculated from the first picking up to the last harvesting continued to (June $30^{\text {th }}$ ) for 16 times of pickings. Number of fruits $/$ plants, fruit length $(\mathrm{cm})$, fruit diameter $(\mathrm{cm})$ and average fruit weight $(\mathrm{g})$ were measured in this investigation.

In order to determine the mineral contents of plant leaves and fruit, dry samples of leaves and fruits were finely ground for chemical analysis. The oven dried plant material samples were wet digested by using concentrate of $\mathrm{H}_{2} \mathrm{SO}_{4} / \mathrm{H}_{2} \mathrm{O}_{2}$ (Lowther, 1980). Mineral elements $\mathrm{N}, \mathrm{P}$ and $\mathrm{K}$ were determined in leaves and fruit using the method described by A.O.A.C. (1990), Chapman and Pratt (1978). Data were statistically analyzed using the SAS program (SAS, 2001) and treatments means were compared using Duncan's Multiple Range test at 5\% level of probability.

\section{Results and Discussion}

The results of the soil analysis before cultivated (Table 1) showed that the soil used in the experiment was sand texture. The amounts of available macro and micro-elements were in the range of medium availability to plants as compared to standard values (Soltanpour, 1985). The amount of available phosphorus of the soil was below the range of high availability $(27.5 \mathrm{mg} / \mathrm{kg})$ according to Landon (1991). This finding further signifies that the soil requires external application of nutrients for high growth and yield of the crop. On the other hand the results of the soil analysis after planting (Table 2 ) indicated that there are treatments which increased the amount of available macro elements above the range of the require for the plants and such as using chicken manure which enhanced soil fertility. 


\section{Growth and yield:}

Table (5) showed that organic fertilizers such as (plant composted and chicken manure) and bio fertilizer (AM fungi) and their combinations caused significant differences in all morphological characters as compared to the control treatment. The highest squash plant height, No. leaves/plant, Leaf area index was recorded with 50\% chicken manure + AM fungi followed by $100 \%$ chicken manure. However the lowest mean number of plant height, No. leaves/plant, Leaf area index were recorded with control treatment (recommended doses of chemical fertilizers N,P,K), that were true in both growing seasons. It was clear that, chicken manure application resulted in considerable increase on the productivity of fruits and the most of growth parameters including; plant height, number of leaves / plant. These findings were similar to those reported by other researchers (Elyass, 2000). Also, the positive effect of chicken manure on growth parameters obtained in this study was supported by results of Shafeek et al., (2015) who stated that addition of manure significantly increased plant height in cantaloupe plants. Similarly, Oje et al. (2014) stated that the use of organic fertilizer such as chicken manure in cultivation of watermelon could be applied as alternative to mineral fertilizer for enhancing plant vegetative growth and yield.

Table 5: Effect of Chicken manure, Compost and AMF on morphological characters of summer squash (El-Askandarani sp.) for two seasons 2107-2018.

\begin{tabular}{|c|c|c|c|c|c|c|}
\hline \multirow[b]{2}{*}{ Treatments } & \multicolumn{2}{|c|}{ Plant height (CM) } & \multicolumn{2}{|c|}{ No. Leaves/ Plant } & \multicolumn{2}{|c|}{ Leaf area index } \\
\hline & 2017 & 2018 & 2017 & 2018 & 2017 & 2018 \\
\hline AMF & $91.60 \mathrm{bc}$ & $82.05 \mathrm{c}$ & $20.00 \mathrm{c}$ & $32.65 \mathrm{f}$ & $1.67 \mathrm{~cd}$ & $1.47 \mathrm{f}$ \\
\hline $100 \% \mathrm{COM}$ & $72.80 \mathrm{e}$ & $49.20 \mathrm{~g}$ & $17.57 \mathrm{~d}$ & $25.28 \mathrm{~h}$ & $2.20 \mathrm{bc}$ & $1.67 \mathrm{e}$ \\
\hline $100 \%$ Ch.M & $93.00 \mathrm{~b}$ & $93.23 \mathrm{~b}$ & $20.23 \mathrm{c}$ & $61.88 \mathrm{a}$ & $2.17 \mathrm{bc}$ & $1.83 \mathrm{~d}$ \\
\hline $50 \%$ COM + $50 \%$ Ch.M & $89.60 \mathrm{c}$ & $63.54 \mathrm{e}$ & $21.00 \mathrm{bc}$ & $54.45 \mathrm{~b}$ & $2.43 \mathrm{ab}$ & $2.43 \mathrm{c}$ \\
\hline $50 \%$ COM + AMF & $89.90 \mathrm{c}$ & $72.20 \mathrm{~d}$ & $21.90 \mathrm{~b}$ & $37.10 \mathrm{e}$ & $2.57 \mathrm{ab}$ & $2.43 \mathrm{c}$ \\
\hline 50\% Ch.M + AMF & $98.30 \mathrm{a}$ & $105.95 \mathrm{a}$ & $24.67 \mathrm{a}$ & $42.16 \mathrm{~d}$ & $2.63 \mathrm{ab}$ & $2.73 \mathrm{~b}$ \\
\hline $33.5 \%$ COM+33.5\% Ch.M+ AMF & $87.50 \mathrm{~d}$ & $55.91 \mathrm{f}$ & $22.57 \mathrm{~b}$ & $47.92 \mathrm{c}$ & $2.93 \mathrm{a}$ & $3.13 \mathrm{a}$ \\
\hline Control (NPK) & $64.43 \mathrm{f}$ & $42.72 \mathrm{~h}$ & $15.10 \mathrm{e}$ & $28.79 \mathrm{~g}$ & $1.27 \mathrm{~d}$ & $1.27 \mathrm{~g}$ \\
\hline
\end{tabular}

$\mathrm{AMF}=($ Mycorrhizal fungi), $\mathrm{COM}=($ Compost $)$ and Ch.M $=($ Chicken manure $)$.

Results of shoot and root dry weight as recorded in (Table 6) showed that, the highest squash mean numbers of shoot and root dry weight were recorded at 50\% chicken manure + AM fungi but the highest mean number of cholorphyll reading in green stage was produced by $50 \%$ compost $+50 \%$ chicken manure. There were no significant differences between $100 \%$ chicken manure and 50\% chicken manure + AM fungi treatment. These results led to reduce the amount of chicken manure with $50 \%$ because it was expensive than AM fungi. Having done the similar work on potato plants Sarhan (2008) reported that increase in yield was due the treatment of the soil with AM fungi. However the lowest mean numbers of shoot, root dry weight and cholorphyll were recorded with control treatment. That were true in both growing seasons. Improving vegetative growth parameters due to treatment of compost compared with other treatments can be attributed to that applying mineral $\mathrm{N}$ stimulated the rate of decomposition of compost and produced higher humus substances which in turn improve the physical and chemical properties of the soil as well as increase both the exchangeable water soluble of nutrients and their uptake this are in agreement with Saad Abou-El-Hassan et al.,(2019).

Table 6: Effect of Chicken manure, Compost and AMF on morphological characters of summer squash (ElAskandarani sp.) for two seasons 2107-2018.

\begin{tabular}{|c|c|c|c|c|c|c|}
\hline \multirow[t]{2}{*}{ Treatments } & \multicolumn{2}{|c|}{$\begin{array}{l}\text { Chlo. In green stage } \\
\text { (SPAD) }\end{array}$} & \multicolumn{2}{|c|}{ Shoot dry weight(g/plant) } & \multicolumn{2}{|c|}{$\begin{array}{c}\text { Root dry } \\
\text { weight(g/plant) }\end{array}$} \\
\hline & 2017 & 2018 & 2017 & 2018 & 2017 & 2018 \\
\hline AMF & $47.73 \mathrm{~cd}$ & $29.54 \mathrm{e}$ & $47.87 \mathrm{c}$ & $55.06 \mathrm{~d}$ & $2.17 \mathrm{bc}$ & $1.94 \mathrm{e}$ \\
\hline $100 \%$ COM & $44.97 \mathrm{de}$ & $22.88 \mathrm{~g}$ & $48.47 \mathrm{c}$ & $62.56 \mathrm{c}$ & $2.00 \mathrm{c}$ & $1.51 \mathrm{~g}$ \\
\hline $100 \%$ Ch.M & $48.83 b c$ & $33.57 \mathrm{~d}$ & $64.87 \mathrm{~b}$ & $71.09 \mathrm{~b}$ & $2.50 \mathrm{~b}$ & $2.52 \mathrm{c}$ \\
\hline $50 \%$ COM+50\%Ch.M & $56.30 \mathrm{a}$ & $49.26 \mathrm{a}$ & $47.27 \mathrm{c}$ & $48.44 \mathrm{e}$ & $2.10 \mathrm{c}$ & $1.72 \mathrm{f}$ \\
\hline $50 \%$ COM+AMF & $46.67 \mathrm{cde}$ & $26.00 \mathrm{f}$ & $46.03 \mathrm{c}$ & $37.52 \mathrm{~g}$ & $2.23 \mathrm{bc}$ & $2.22 \mathrm{~d}$ \\
\hline $50 \%$ Ch.M+AMF & $50.97 \mathrm{~b}$ & $38.15 \mathrm{c}$ & $80.50 \mathrm{a}$ & $80.77 \mathrm{a}$ & $3.13 \mathrm{a}$ & $2.86 \mathrm{~b}$ \\
\hline $33.5 \%$ COM+33.5\%Ch.M+ AMF & $51.10 \mathrm{~b}$ & $43.35 b$ & $46.60 \mathrm{c}$ & $42.63 f$ & $3.10 \mathrm{a}$ & $3.25 \mathrm{a}$ \\
\hline Control (NPK) & $44.00 \mathrm{e}$ & $20.13 \mathrm{~h}$ & $30.83 \mathrm{~d}$ & $32.58 \mathrm{~h}$ & $1.97 \mathrm{c}$ & $1.31 \mathrm{~h}$ \\
\hline
\end{tabular}

$\mathrm{AMF}=(\mathrm{AM}$ fungi) $\mathrm{COM}=($ Compost $)$ and $\mathrm{Ch} \cdot \mathrm{M}=($ Chicken manure $)$. 
Data in table (7) showed that all treatments were increased the productivity of the fruits. Significant differences were observed of the mean numbers of fruit length, fruit diameter and No, of fruits/ plant. The highest mean number of fruit length, was recorded with $100 \%$ chicken manure followed by $33.5 \%$ compost $+33.5 \%$ chicken manure + AM fungi more than $100 \%$ compost. Meanwhile the highest mean number of fruit diameter was estimated at $50 \%$ compost + AM fungi in both seasons or by $100 \%$ chicken manure in the first season only. Meanwhile the highest number of fruits / plant was produced by $50 \%$ chicken manure + AM fungi followed by the mixture of $33.5 \%$ compost $+33.5 \%$ chicken manure + AM fungi and the least was produced in control treatment. The positive effect of chicken manure on fruit yield of squash in this study was supported by results of many researchers, (Kumar et al., 2017; Eifediyi et al., 2017) who found that manure application resulted in highly significant in yield and yield components. From above findings; it appears that, chicken manure promotes crop growth. This could be attributed to the fact that, chicken manure provides the soil with essential elements such as nitrogen, phosphorous and potassium for a powerful squash growth. Also, the improvement in quantitative characteristics of yield traits as a result of using AMF inoclum or in interaction with organic fertilizer might be due to the plants without mycorrhiza completely depends on their root growth to take up $\mathrm{P}$ and other nutrients $(\mathrm{N}, \mathrm{K}, \mathrm{Zn}, \mathrm{Ca}, \mathrm{Mg}$ and $\mathrm{Fe}$ ) and water from the soil. But in plants with AM fungi depends on other mechanisms beside the root growth, the extrametrical mycorrhizal hyphae which absorbing and trans locating nutrients to associated plants (Grant et al., 2005 and Abou El Seoud, 2005). Also, AM fungi may have biochemical capabilities for increasing the supply of available $\mathrm{P}$ and other immobile nutrients. These capabilities my involve increases in root phosphatase activity, excretion of chelating agents, and rhizosphere acidification (Abou-El-Hassan et al., 2017).

Table 7: Effect of Chicken manure, Compost and AMF on yield and yield components of summer squash (ElAskandarani sp.) for two seasons 2107-2018.

\begin{tabular}{|c|c|c|c|c|c|c|}
\hline \multirow{2}{*}{ Treatments } & \multicolumn{2}{|c|}{ Fruit length (cm) } & \multicolumn{2}{|c|}{ Fruit diameter(cm) } & \multicolumn{2}{|c|}{ No. of fruits / plant } \\
\hline & 2017 & 2018 & 2017 & 2018 & 2017 & 2018 \\
\hline AMF & $8.50 \mathrm{~d}$ & $5.77 \mathrm{~h}$ & $2.40 \mathrm{c}$ & $1.83 \mathrm{~h}$ & $5.33 \mathrm{~cd}$ & $4.64 f$ \\
\hline $100 \%$ COM & $10.83 \mathrm{bc}$ & $11.03 \mathrm{c}$ & $2.90 \mathrm{bc}$ & $2.73 \mathrm{e}$ & $6.00 \mathrm{bcd}$ & $5.26 \mathrm{e}$ \\
\hline $100 \%$ Ch.M & $13.67 \mathrm{a}$ & $14.17 \mathrm{a}$ & $3.93 a$ & $3.97 \mathrm{~b}$ & $6.00 \mathrm{bcd}$ & $5.99 \mathrm{~d}$ \\
\hline $50 \%$ COM + 50\% Ch.M & $9.13 \mathrm{~cd}$ & $6.63 \mathrm{~g}$ & $2.77 \mathrm{bc}$ & $2.43 f$ & $5.00 \mathrm{~d}$ & $4.09 \mathrm{~g}$ \\
\hline $50 \%$ COM + AMF & $10.40 \mathrm{c}$ & $8.50 \mathrm{e}$ & $3.90 \mathrm{a}$ & $4.60 \mathrm{a}$ & $6.67 \mathrm{bc}$ & $6.79 \mathrm{c}$ \\
\hline 50\% Ch.M + AMF & $10.67 \mathrm{bc}$ & $9.67 \mathrm{~d}$ & $2.97 \mathrm{bc}$ & $3.13 \mathrm{~d}$ & $8.67 \mathrm{a}$ & $8.80 \mathrm{a}$ \\
\hline $33.5 \%$ COM $+33.5 \%$ Ch.M+ AMF & $12.47 \mathrm{ab}$ & $12.50 \mathrm{~b}$ & $3.10 \mathrm{~b}$ & $3.53 \mathrm{c}$ & $7.00 \mathrm{~b}$ & $7.73 b$ \\
\hline Control (NPK) & $10.27 \mathrm{~cd}$ & $7.53 \mathrm{f}$ & $2.50 \mathrm{bc}$ & $2.13 \mathrm{~g}$ & $5.00 \mathrm{~d}$ & $3.59 \mathrm{~h}$ \\
\hline
\end{tabular}

$\mathrm{AMF}=($ AMfungi) $\mathrm{COM}=($ Compost $)$ and $\mathrm{Ch} \cdot \mathrm{M}=($ Chicken manure $)$.

Results of average fruit weight (Table 8) showed that, the highest squash average fruit weight was recorded with $100 \%$ chicken manure followed by $33.5 \%$ compost $+33.5 \%$ chicken manure + AM fungi, then $100 \%$ compost + AM fungi . However the lowest squash average fruit weight was recorded with (control treatment). That was true in both growing seasons. Concerning the fruit yield ( $\mathrm{kg} / \mathrm{fed}$.$) , total yield (\mathrm{kg} / \mathrm{fed}$.) as shown in (Table 8). The highest mean values of fruit yield / plant and total yield were recorded with $33.5 \%$ compost $+33.5 \%$ chicken manure + AM fungi, followed by $50 \%$ chicken manure + AM fungi, then $100 \%$ chicken manure. However the lowest squash fruit yield and total yield were recorded with control treatment. That was true in both growing seasons. The superiority of $33.5 \%$ compost $+33.5 \%$ chicken manure + AM fungi for enhancing yield and its component of summer squash plants. This may be due to that such organic manure is capable as a source of many essential macro and micro nutrients for a good nutritional in cucumber plants (Hongmei et al., 2014) to serve as a good natural soil texture conditioner being rich in organic matter and increase availability and uptake of NPK which positively reflected on plant cell elongation and division as well as stimulate photosynthesis and metabolic processes and fruiting. The obtained results are in accordance with those of Jyoti and Singh et al., (2012); Swelam (2012); Baghdadi et al., (2012); Shehata et al., (2012); Mahmoud et al.,(2013). As for mycorrhiza may increase nutrient uptake by reducing the distance that nutrients must diffuse to plant roots ( Abou El Seoud, 2005). Mycorrhizal roots due to their external hyphae that are capable of absorbing and translocating nutrients can explore more soil volume than the non-mycorrhizal roots and increase the supply of the slowly diffusing ions such as phosphate to the plant (Khaliq and Sanders, 2000). Also, the distribution 
of hyphae in soil zones where the roots are absent (the micro-sized cross-section of the hyphae facilitates the penetration of much smaller soil pore where roots cannot penetrate), as well as the bigger contact of the hyphae with the soil contributes largely to the increased nutrient and water uptake. Therefore, this treatment (the mixture of $33.5 \%$ compost $+33.5 \%$ chicken manure as organic fertilizers + AM fungi as a biofertilizer) caused a high improvement in plant hormones production like auxin, IAA and gibberellins in addition to the vitamins (Biotin, folic acid and vitamin B). The effect of organic fertilizers on quantitative yield might be due to its additive effect on vegetative growth of the crop ultimately affecting the yield (Table 8). The physiological processes especially photosynthesis and synthesis of amino acids and proteins were improved by the treatments that consequently resulted in an increase in productivity per unit area. The mentioned results are in agreement with those of Sarhan et al., (2012) on squash plant by adding organic fertilizer.

Table 8: Effect of Chicken manure, Compost and AMF on yield and yield components of summer squash (ElAskandarani sp.) for two seasons 2107-2018.

\begin{tabular}{|c|c|c|c|c|c|c|}
\hline \multirow[t]{2}{*}{ Treatments } & \multicolumn{2}{|c|}{$\begin{array}{c}\text { Average fruit weight } \\
\text { (g) }\end{array}$} & \multicolumn{2}{|c|}{$\begin{array}{c}\text { Early yield } \\
\text { (kg/fed.) }\end{array}$} & \multicolumn{2}{|c|}{$\begin{array}{c}\text { Total yield } \\
\text { (kg/fed.) }\end{array}$} \\
\hline & 2017 & 2018 & 2017 & 2018 & 2017 & 2018 \\
\hline AMF & $34.90 \mathrm{e}$ & $63.23 \mathrm{~h}$ & $77.94 d$ & $100.57 \mathrm{~d}$ & $623.54 d$ & $804.57 \mathrm{~d}$ \\
\hline $100 \% \mathrm{COM}$ & $51.67 \mathrm{~cd}$ & $81.67 f$ & $71.66 \mathrm{~d}$ & $68.51 \mathrm{~g}$ & $573.26 \mathrm{~d}$ & $548.11 \mathrm{~g}$ \\
\hline $100 \%$ Ch.M & $143.70 \mathrm{a}$ & $154.73 \mathrm{a}$ & $87.69 \mathrm{c}$ & $114.09 \mathrm{c}$ & $701.49 \mathrm{c}$ & $912.69 \mathrm{c}$ \\
\hline $50 \%$ COM + $50 \%$ Ch.M & $54.30 \mathrm{~cd}$ & $92.70 \mathrm{e}$ & $77.63 \mathrm{~d}$ & $88.31 \mathrm{e}$ & $621.03 \mathrm{~d}$ & $706.51 \mathrm{e}$ \\
\hline $50 \%$ COM + AMF & $59.90 \mathrm{c}$ & $119.84 \mathrm{c}$ & $75.43 \mathrm{~d}$ & $77.63 f$ & $603.43 \mathrm{~d}$ & $621.03 f$ \\
\hline 50\% Ch.M + AMF & $54.70 \mathrm{~cd}$ & $105.40 \mathrm{~d}$ & $88.31 b$ & $129.80 b$ & $957.94 b$ & $1038.40 \mathrm{~b}$ \\
\hline $33.5 \%$ COM+33.5\%Ch.M+ AMF & $74.50 \mathrm{~b}$ & $136.13 b$ & $141.43 \mathrm{a}$ & $147.40 \mathrm{a}$ & $1131.43 \mathrm{a}$ & $1179.20 \mathrm{a}$ \\
\hline Control (NPK) & $42.27 \mathrm{de}$ & $71.91 \mathrm{~g}$ & $14.77 \mathrm{e}$ & $60.34 \mathrm{~h}$ & $118.42 \mathrm{e}$ & $482.74 h$ \\
\hline
\end{tabular}

$\mathrm{AMF}=($ AMfungi $), \mathrm{COM}=($ Compost $)$ and $\mathrm{Ch} \cdot \mathrm{M}=($ Chicken manure $)$

\section{Chemical composition:}

N, P and K concentrations in leaves: Data presented in table (9) indicated that the application of inorganic fertilizer (recommended dose of chemical fertilizer N,P and $\mathrm{K}$ ) increased $\mathrm{N}$ and $\mathrm{P}$ content in leaves also, in the same trend either the mixture of $50 \%$ chicken manure + AM fungi or $50 \%$ compost $+\mathrm{AM}$ fungi, gave the highest mean values of $\mathrm{N}$ and $\mathrm{P}$ content in leaves compared with other treatments. On the other hand application of 50\% compost $+\mathrm{AM}$ fungi gave the highest mean values of K content in leaves. Similar results were recorded in both seasons, several researchers found that inoculation with AM fungi lead to enhance p up take (Al-Hmoud and Al-Momany, 2017), also, onion growth plants (Wang et al., 2011 and Tawaraya et al., 2012) and leek growth plants than those of non-inoculated plants grown in $\mathrm{P}$ deficient soil. The hyphal mycelium increases the total absorption surface of infected plants and this improves its access of immobile elements such as $\mathrm{P}, \mathrm{Cu}$ and $\mathrm{Zn}$. Taha et al.(2011) on squash found that fertilizing plants with organic fertilizer increased macro-and microelements contents in leaves .

Table 9: Effect of Chicken manure, Compost and AMF on leaves nutrient contents of summer squash (ElAskandarani sp.) for two seasons 2107-2018.

\begin{tabular}{lcccccc}
\hline \multirow{2}{*}{ Treatments } & \multicolumn{2}{c}{$\mathbf{N} \%$ in leaves } & \multicolumn{2}{c}{ P \% in leaves } & \multicolumn{2}{c}{ K \% in leaves } \\
& $\mathbf{2 0 1 7}$ & $\mathbf{2 0 1 8}$ & $\mathbf{2 0 1 7}$ & $\mathbf{2 0 1 8}$ & $\mathbf{2 0 1 7}$ & $\mathbf{2 0 1 8}$ \\
\hline AMF & $0.83 \mathrm{~b}$ & $0.58 \mathrm{~g}$ & $0.30 \mathrm{~b}$ & $0.52 \mathrm{f}$ & $7.53 \mathrm{c}$ & $10.24 \mathrm{c}$ \\
$\mathbf{1 0 0 \% C O M}$ & $1.03 \mathrm{ab}$ & $0.97 \mathrm{c}$ & $0.43 \mathrm{~b}$ & $0.75 \mathrm{c}$ & $7.20 \mathrm{c}$ & $9.01 \mathrm{~d}$ \\
$\mathbf{1 0 0 \% C h . M}$ & $0.90 \mathrm{~b}$ & $0.66 \mathrm{f}$ & $0.20 \mathrm{~b}$ & $0.40 \mathrm{~h}$ & $5.43 \mathrm{de}$ & $6.97 \mathrm{f}$ \\
$\mathbf{5 0 \%}$ COM+50 \%Ch.M & $1.03 \mathrm{ab}$ & $0.75 \mathrm{e}$ & $0.83 \mathrm{a}$ & $0.86 \mathrm{~b}$ & $1.87 \mathrm{f}$ & $5.40 \mathrm{~h}$ \\
$\mathbf{5 0 \%}$ COM+AMF & $0.97 \mathrm{ab}$ & $0.86 \mathrm{~d}$ & $0.33 \mathrm{~b}$ & $0.59 \mathrm{e}$ & $14.00 \mathrm{a}$ & $13.22 \mathrm{a}$ \\
$\mathbf{5 0 \%}$ Ch.M+AMF & $1.13 \mathrm{a}$ & $1.10 \mathrm{~b}$ & $0.90 \mathrm{a}$ & $0.98 \mathrm{a}$ & $10.07 \mathrm{~b}$ & $11.63 \mathrm{~b}$ \\
$\mathbf{3 3 . 5 \%}$ COM+33.5\% Ch.M+ AMF & $0.27 \mathrm{c}$ & $0.51 \mathrm{~h}$ & $0.40 \mathrm{~b}$ & $0.67 \mathrm{~d}$ & $5.10 \mathrm{e}$ & $6.14 \mathrm{~g}$ \\
Control (NPK) & $1.17 \mathrm{a}$ & $1.26 \mathrm{a}$ & $0.27 \mathrm{~b}$ & $0.45 \mathrm{~g}$ & $5.77 \mathrm{~d}$ & $7.93 \mathrm{e}$ \\
\hline
\end{tabular}

$\mathrm{AMF}=($ AMfungi), $\mathrm{COM}=($ Compost $)$ and Ch.M=(Chicken manure).

Regarding, N, P and K concentrations in fruits: Data presented in table (10) showed that the mixture of $33.5 \%$ compost $+33.5 \%$ chicken manure + AM fungi increased $\mathrm{N}$ content in fruits meanwhile application of AM fungi treatment or mixed of $50 \%$ compost $+50 \%$ chicken manure 
treatment gave the highest mean values of $\mathrm{P}$ content in fruits compared with other treatments. On the other hand application of $100 \%$ chicken manure treatment gave the highest mean values of K content in fruits. Furthermore, the lowest mean value were produced by control treatment. Similar results were recorded in both seasons. This are in accordance with Clementina (2013) who reported that high concentration of elements in fruits due to adsorption $\mathrm{NH}_{4}{ }^{+}$ion on the surface of compost and became available to plant uptake. Similarly, Ghorbani et al., (2013) stated that applying organic fertilizer with organic manures increased both $\mathrm{N}$ mineralization and nitrification which in turn enhance the access to $\mathrm{NH}_{4}{ }^{+}$and result in greater number of viable cells of nitrifying bacteria, especially with chemical fertilization. Moreover, chicken manure has indirect effect on growth through improving soil physical; chemical and biological properties, and ultimately enhances the vigorous growth of the squash. Furthermore it improves soil aeration, this might explain the consistent increase in fruit number, fruit weight and fruit length by application of the mixture of $33.5 \%$ compost $+33.5 \%$ chicken manure + AM fungi, observed in this study. In the same line, Stephanie et al., (2011) reported that arbuscular mycorrhiza (AM fungi) play an important role in plant P content. Also, Tawaraya et al., (2012) reported that shoot $\mathrm{P}$ content of onion inoculated plants was higher than that of noninoculated plants grown in P deficient soil. In this respect, Sadek and Youssef (2014) found that compost and effective microorganism treatments enhanced available nitrogen in soil and soil organic matter and reduced soil $\mathrm{pH}$ compared to chemical treatment. Lasmini et al. (2015) found that the application of compost increased organic carbon, nitrogen and phosphorous in soil more than application of $\mathrm{N}$ mineral fertilizers. Compost combined with application of $\mathrm{N}$ mineral fertilizers was the best treatment for increasing soil fertility and plant growth (Lasmini et al., 2015; Singh et al., 2012). Abbas et al., (2014) showed that the addition of compost of rice straw with mineral N, humic acidor EM had a high significant influence on potato plant growth.

Table 10: Effect of Chicken manure, Compost and AMF on fruits nutrient contents of summer squash (ElAskandarani sp.) for two seasons 2107-2018.

\begin{tabular}{|c|c|c|c|c|c|c|}
\hline \multirow{2}{*}{ Treatments } & \multicolumn{2}{|c|}{$\mathrm{N} \%$ in fruits } & \multicolumn{2}{|c|}{$P \%$ in fruits } & \multicolumn{2}{|c|}{$\mathrm{K} \%$ in fruits } \\
\hline & 2017 & 2018 & 2017 & 2018 & 2017 & 2018 \\
\hline AMF & $1.00 \mathrm{~cd}$ & $1.75 \mathrm{e}$ & $0.90 \mathrm{a}$ & $1.47 \mathrm{a}$ & $12.30 \mathrm{~d}$ & $9.78 \mathrm{~h}$ \\
\hline $100 \% \mathrm{COM}$ & $1.80 \mathrm{~b}$ & $2.58 \mathrm{~b}$ & $0.63 \mathrm{ab}$ & $0.99 \mathrm{~d}$ & $16.67 \mathrm{c}$ & $14.35 \mathrm{e}$ \\
\hline $100 \%$ Ch.M & $1.07 \mathrm{~cd}$ & $1.99 \mathrm{~d}$ & $0.30 \mathrm{~b}$ & $0.77 f$ & $23.80 \mathrm{a}$ & $23.94 \mathrm{a}$ \\
\hline $50 \%$ COM+50 \%Ch.M & $1.33 \mathrm{c}$ & $2.27 \mathrm{c}$ & $0.90 \mathrm{a}$ & $1.29 b$ & $12.47 \mathrm{~d}$ & $11.11 \mathrm{~g}$ \\
\hline $50 \%$ COM+AMF & $0.93 \mathrm{~d}$ & $1.54 \mathrm{f}$ & $0.63 \mathrm{ab}$ & $1.13 \mathrm{c}$ & $19.00 \mathrm{~b}$ & $16.30 \mathrm{~d}$ \\
\hline $50 \%$ Ch.M+AMF & $0.73 d$ & $1.26 \mathrm{~h}$ & $0.13 b$ & $0.67 \mathrm{~g}$ & $22.27 \mathrm{a}$ & $18.52 \mathrm{c}$ \\
\hline 33.5\%COM+33.5\%Ch.M+ AMF & $2.50 \mathrm{a}$ & $2.93 \mathrm{a}$ & $0.47 \mathrm{ab}$ & $0.87 \mathrm{e}$ & $22.93 \mathrm{a}$ & $21.05 b$ \\
\hline Control (NPK) & $0.87 \mathrm{~d}$ & $1.36 \mathrm{~g}$ & $0.13 b$ & $0.60 \mathrm{~h}$ & $13.90 \mathrm{~d}$ & $12.61 \mathrm{f}$ \\
\hline
\end{tabular}

\section{Conclusion}

It could be concluded that application of the mixture of $33.5 \%$ compost $+33.5 \%$ chicken manure plus AM fungi treatment was superior of the yield and fruit quality of compared treatments to recommended mineral fertilizers. Integration of compost, chicken manure and AM fungi can be used as an alternative to mineral fertilizers to produce a superful and healthy yield of squash plant.

\section{Future prospective:}

Further investigation intends to purify soils from chemical pollution hazard. We using the mixture of different organic fertilizers and biofertilizers to obtain a healthy and fertility soils, safty food productivity and cleany environmental gift.

\section{References}

A.O.A.C. 1990. Official methods of analysis. Association of official analytical chemists. 15th ed. Washington D.C., USA.

Abbas, M.S., A.M. El-Ghamry, E.M. Selim, E.I. Gaber and A.H. Bazeed. 2014. Influence ofcomposting of rice straw with effective microorganisms and humic acid on quality and quantityof potato plants (Solanum tuberasum L.) through fertigation system under sandy soilconditions. Middle East J. Applied Sci., 4: 484-493. 
Abd El-Rahman, S.Z. and F. Hosney. 2001. Effect of organic and inorganic fertilizer on growth and yield, fruitlity and storability of eggplant. J. Agric. Sci. 26(10): 6307-6321.

Abou El Seoud, I.I. A. 2005. Influence of mycorrhizae and phosphate mobilizing bacteria on P nutrition of some vegetable crops. PhD thesis, Faculty of Agriculture (Saba Basha), Alexandria University, Egypt.pp. 174.

Abou-El-Hassan S., M. Abd Elwanis and M.Z. El-Shinawy.2017. Application of compost and vermicompost as substitutes for mineral fertilizers to produce green beans Egypt. J. Hort., 44(2): $155-163$.

Abou-El-Hassan S., M.A.A. Abdrabbo and A.H. Desoky.2014. Enhancing organic production of cucumber by using plant growth promoting rhizobacteria and compost tea under sandy soil condition. Res. J. of Agric. And Bio. Sci., 10(2): 162-169.

Al-Hmoud, G. and A. Al-Momany. 2017. Effect of Four Mycorrhizal Products on Squash Plant Growth and its Effect on Physiological Plant Elements. Adv. Crop Sci. Tech. 2017,I SSN: 2329$8863,5(1): 1-6$.

Baghdadi,H., J. Daneshian, M. Yousefi, M. Alimohamadi and M. Kheybari. 2012.Influence of cattle manure and mycorrhiza fungi on vegetative growth of pumpkin under water deficit condition. International J. Agric. Crop Sci., 4 (18): 1362-1363.

Chapman, H.D. and P.F. Pratt. 1978. Methods of analysis for soils. Plant and water Univ. California. Div. Agric. Sci., 16-38.

Clementina, U. 2013. The impact of organic and inorganic manure on the cultivation of pumpkin ( Cucurbita maxima). J. of Pharmacy and Bio. Sci. 8: 18-20.

Eifediyi, E.K., S.U.Remison, H.E. Ahamefule, K.O. Azeez and P.Fesobi, 2017. Performance of watermelon (Citrullus Lanatus L.) in response to organic and NPK fertilizers. Acta Uni. Sapientiae Agric. And Environment. 9:5-175.

Elyass, S.K. 2000. Response of Muskmelon (Cucumis melo var Reticulatus Naud.) to Nitrogen and Phosphorus Fertilization. M.Sc. Thesis, University of Gezira, Wad Medani, Sudan.

Farrag, D.E. 2009. Effect of organic and mineral fertilizers and biostimulants on growth, yield and quality of cantaloupe plant (Cucumis melo var. cantaloupensis, L.). Ph.D. Fac. Agric. Kafrelsheikh Univ., Egypt.

Ghorbani, R., M. Jahan, A. Koocheki, M. Nassiri and M.D.Salari.2013. The effect of manure application and branch management methods on some agro ecological aspects of summer squash ( Cucurbita pepo L.) in a low input cropping system.Int.J.of Agric.Sci. 3: 428-434.

Grant, C., S. Bittman, M. Montreal, C. Plenchette and C. Morel. 2005. Soil and fertilizer phosphorus: Effects on plant P supply and mycorrhizal development. Can. J. Plant Sci., 85: 3-14.

Hong-mei, Z., J.Hai-jun, D.Xiao-tao and H.Ting. 2014. Effects of application of organic and inorganic fertilizer on the growth, yield quality of cucumber in greenhouse. J. of P.N. and Fertilizer.Pp.247-253.

Khaliq, A. and F. E. Sanders. 2000.Effects of vesicular arbuscular mycorrhizal inoculation on the yield and phosphorus uptake of field grown Barley. Soil Biol. Biochem., 32:1691 - 1696.

Kumar, S., N. Datt, S.K. Sandal and S.K. Sharma.2017. Effect of cow urine and biofertilizer based fertigation schedule at varying levels of drip irrigation on yield and growth , quality parameters and economics of cucumber under protected condition. Inter. J. of Curr. Microbiology and App.Sci.6:1242-1249.

Landon, J.R. 1991. Booker tropical soil manual: A handbook for soil survey and agricultural and evaluation in the tropics and sub-tropics. Longman Scientific and Technical, Essex, New York. p. 474.

Lasmini, S.A., Z. Kusuma, M. Santoso and A.Abadi.2015. Application of organic and inorganic fertilizer improving the quantity and quality of shallot yield on dry land. Int. J. Sci. Tech. Res. 4(4): 243-246.

Mahmoud, R.A., M. El-Desouki, M. Abdel-Mouty and A.H. Ali. 2013.Effect of compost and yeast extract application on the pea plant growth, pod yield and quality. J. of Applied. Sci. Res.,9(1): 149-155.

Ministry of Agriculture and Land Reclamation, Economic Affairs Sector 2015. The Indicators Agriculture Statistics. 
Ojo, J.A., A.A. Olowoake and A.Obembe.2014. Efficacy of agronomical fertilizer and un-amended compost on the growth and yield of watermelon (Citrullus lanatus Thumb) in Ilorin Southern Guinea Savanna zone of Nigerria. Int. J. Recycl.Org. Waste Agriculture 3: 121-125.

Page, A.L., R.H. Miller and D.R. Keeney. 1982. Methods of Soil Analysis. Part 2 - Chemical and Microbiological Properties, 2nd Edition. Agronomy Society of America. Madison, WI.

Pellegrino, E., S. Bedini, L. Avio, E. Bonari and M. Giovannetti, 2011. Field inoculation effectiveness of native and exotic arbuscular mycorrhizal fungi in a Mediterranean agricultural soil. Soil Biology and Biochemistry, 43: 367-376.

Roods, F.M. and M.E. Blood-Worth.1964. Area measurement of cotton leaf by dry weight method, Agronomy J., 56(5): 520-525.

Rouphael, Y. and M. Cardarelli, 2010. Enhancement of alkalinity tolerance in two cucumber genotypes inoculated with an arbuscular mycorrhizal biofertilizer containing Glomus intraradices. Biol. Fertil. Soils, 46:499-509.

Saad Abou-El-Hassan, H. G. Elmehrat, W. M. Ibrahim and A. A. Ragab.2019. Applying biofertilizer and different rates of compost for the production of squash. Middle East Journal of Applied Sciences, vol. 9(2): 319-325.

Sadek, I.I. and M.A. Youssef.2014. Effect of different types of fertilization and some climatic factors on soil carbon dioxide (CO2) emission. N. Y. Sci. J., 7: 1-12.

Sarhan, T. Z. 2008. Effect of biological fertilizers, animal residues, and urea on growth and yield of potato plant c.v. Desiree (Solanum tuberosom L.). Ph.D Dissert., Hort. Sci. \& Landscape Design (Vegetable). Univ. of Mosul, College of Agric. \& Forestry. Iraq.

Shafeek, M.R., A.M. Shaheen, E.H. Abd El-Samad, F.A. Rizk and F.S. Abd El-Al. 2015. Response of growth, yield and fruit quality of cantaloupe plants (Cucumis melo L.) to organic and mineral fertilization. Middle East Journal of Applied Sciences. 5: 76-82.

Shehata,S.A., Y.M. Ahmed, E.T. Youssef and M.A. Azoz.2012. Influence of some organic and inorganic fertilizer on vegetative growth, yield and yield components of cucumber plants. Research J. of Agric. and Biological Sci., 8(2): 108-114.

Singh, D.P., U.C. Mishra, H.G. Prakash and O. Mishra. 2012. Role of organic farming on yield and economics of bottle gourd after vegetable pea. Int. J. Agric. Sci., 8: 165-167.

Soil Health, 2010. Effect of arbuscular mycorrhizal fungi on plants. Soil Health-part3, 3.2 Mycorrhizal associations. http://www.soilhealth.com/soils.

Statistical Analysis System. 2001. SAS/STAT Users' Guide for Personal Computers. Release 6.12, SAS Instt. Inc., Cary, N.C., SA. The national workshop for production and utilizing Biofertilizer Amman, Jordan,Arab Countries Union, Arab Agric. Dev. Org (1988).

Stephanie, J. W. and T. R. Cavagnaro, 2011. Arbuscular mycorrhizas modify tomato responses to soil zinc and phosphorus addition. Biol. Fertil. Soils, 47:621-631.

Swelam,W.M.E. 2012. Effect of organic fertilizer, biofertilizer and some foliar application treatmetns on the yield and quality of sweet pepper. Ph.D. Thesis,Fac. Agric.,Mansoura Univ.,Egypt.

Taha, Z.S., H. Ghurbabt and A.T. Jiyan, 2011. Effect of bio-and organic fertilizers on growth, yield and fruit quality of summer squash. Sarhad J. Agric. 27, No.(3).

Tawaraya, K., R. Hirose and T. Wagatsuma.2012. Inoculation of arbuscular mycorrhizal fungi can substantially reduce phosphate fertilizer application to (Allium fistulosum L.) and achieve marketable yield under field condition. Biol. Fertil. Soils, 48:839-843.

Wang, F. Y. , R. J. Tong, Z. Y. Shi, X. F. Xu, and X. H. He. 2011. Inoculations with Arbuscular mycorrhizal fungi increase vegetable yields and decrease phoxim concentrations in carrot and green onion and their soils. PLoS One, 6(2) :49-69.

Wang, S. G., X. G. Lin, R. Yin and Y. L. Hou.2004. Effect of inoculation with arbuscular mycorrhizal fungi on the degredation of DEHP in soil. J. Enviro. Sci. China, 16: 458-461. 